\title{
Is low birth weight a risk indicator for congenital cytomegalovirus infection?
}

\author{
Zakyieh Al-Hareth $^{1}$, Fawza Monem ${ }^{1}$, Nagwa Abdel Megiud ${ }^{2}$ \\ ${ }^{1}$ Clinical Laboratories Department, Al-Assad Hospital, Damascus University, Syria \\ ${ }^{2}$ Research on Children with special Needs Department, National Research Center, Cairo, Egypt
}

\begin{abstract}
Background: Congenital cytomegalovirus infection is currently the leading cause of congenital infection in $0.2-2.2 \%$ of live births worldwide leading to variable serious sequalae. The aim of the study was to determine if low birth weight is an indicator of CMV congenital infection evidenced by detecting CMV-DNA in umbilical cord blood at the time of delivery.

Methodology: CMV-IgG and IgM antibodies and CMV-DNAemia were assessed in umbilical cord blood of two hundreds newborns, one hundred of whom had birth weight $\leq 2700$ gram and/or head circumference $\leq 32 \mathrm{~cm}$.

Results: CMV-IgM was not detected, while CMV-IgG was positive in 80-90\% of the two hundreds tested newborns. CMV-DNA was detected in four out of the 200 newborns. One of them was over the adopted weight limit (> 2700 gram).

Conclusions: CMV-IgM and IgG antibodies assessment was not a potential discriminative test to identify congenitally infected newborns. In addition, low birth weight and small head circumference at birth failed to predict congenital CMV infection. CMV-DNA detection in umbilical cord blood at the time of delivery using real-time PCR of all newborns is recommended as decisive, rapid and non-invasive test.
\end{abstract}

Key words: congenital CMV, real-time PCR, umbilical cord blood, low-birth weight

J Infect Dev Ctries 2010; 4(1):044-047.

Received 27 September 2009 - Accepted 28 September 2009

Copyright $\odot 2010$ Al-Hareth et al. This is an open-access article distributed under the Creative Commons Attribution License, which permits unrestricted use, distribution, and reproduction in any medium, provided the original work is properly cited.

\section{Introduction}

Congenital cytomegalovirus (CMV) infection is currently the leading cause of congenital infections worldwide occurring in $0.2-2.2 \%$ of live births. The typical clinical symptoms of congenital CMV infection that are found in infected neonates include intrauterine growth retardation, microcephaly with intracranial calcification, hepatosplenomegaly, jaundice, chorioretinitis, thrombocytopenic purpura and anemia $[1,2]$.

Early diagnosis of congenital CMV infection is essential in order to start preemptive treatments and reduce consequent sequelae such as deafness and heart malformation [3]. In mothers at risk of transmitting the virus to their fetuses, prenatal diagnosis can be performed between 21 and 22 weeks of gestation, and the amniotic fluid represents the invasive pathological material of choice to determine intrauterine virus transmission [4].

After birth, all children considered to be at risk of congenital CMV infection are classically assessed by a paediatrician and investigated appropriately within the first three weeks of life. These investigations include confirmation of infection using urine or saliva for CMV culture or PCR, or by testing blood for CMV immunoglobulin M [5].

Screening for congenital CMV infection with quantitative real-time PCR could be easily incorporated into routine labour and delivery care using discarded umbilical cord blood specimens to identify neonates whose infection is otherwise undiagnosed [6], thus reducing consequent sequelae in the CMV congenitally infected newborns.

Since birth weight (BW) and head circumference (HC) are routinely checked at birth for all newborns, our study aimed at investigating whether low birth weight (LBW) is a risk indicator for congenital CMV infection, by performing early non-invasive detection of the virus in the umbilical cord blood using the real-time PCR method.

\section{Methods and Materials}

Specimens

Umbilical cord blood samples (10 $\mathrm{ml}$ each) were collected at the time of delivery from 200 newborns delivered at Al-Zahrawy public hospital and AlSharq private hospital for gynecology and Obstetrics in Damascus, on two days weekly from May 2006 to May 2007. One hundred cord blood samples of these 
were collected from newborns manifesting low birth weight $(\mathrm{BW} \leq 2.7 \mathrm{~kg})$ and small head circumference $(\mathrm{HC} \leq 32 \mathrm{~cm})$ as possible indicators of disease occurrence. Another one hundred similar samples were collected from newborns of $\mathrm{BW}>2.7 \mathrm{~kg}$ and $\mathrm{HC}>32 \mathrm{~cm}$ as a control group. Samples were equally divided in plain (serum) and EDTA (plasma) tubes. Ethical clearance and informed consent were obtained from the mothers.

\section{$C M V$-IgM and CMV-IgG detection}

CMV-IgM and CMV-IgG antibodies were tested in the 200 sera samples on an AxSym system (Abbott Laboratories, Diagnostics Division, Abbott Park, IL 60064 USA) according to the manufacturer's instructions. An ELISA assay index of $\geq 0.5$ was considered positive for CMV-IgM, and a cutoff value of $\geq 15 \mathrm{IU} / \mathrm{ml}$ was considered positive for CMV-IgG.

\section{CMV-DNA real-time PCR}

DNA was extracted from $200 \mu \mathrm{l}$ plasma using a High Pure Viral Nucleic Acid kit (Roche Diagnostics $\mathrm{GmbH}$, Mannheim, Germany) according to the manufacturer's instructions, and was stored at $-80^{\circ} \mathrm{C}$ until testing. Real-time PCR was performed on the LightCycler instrument using LightCycler FastStart DNA Master HybProbe (Roche Diagnostics GmbH, Mannheim, Germany). Primers selected from the glycoprotein B gene region were [7] as follows: CMV-FOR: ATA GGA GGC GCC ACG TAT TC and CMV-REV: TAC CCC TAT CGC GTG TGT TC (Metabion GmbH, Germany). The probes used were [8, 9] CMV-FL: CGT TTC GTC GTA GCT ACG CYT ACA T-fluorescein and CMV-LC: LC Red 640-ACA CCA CTT ATC TRC TGG GCA GCphosphate (Metabion GmbH, Germany). PCRs were carried out as previously described [8].

\section{Results}

CMV-IgM was not detected in any of the 200 newborn samples studied. CMV-IgG was positive in 90/100 (90\%) of LBW group samples (birth weight $\leq$ 2700 gram and head circumference $\leq 32 \mathrm{~cm}$ ), and $80 / 100(80 \%)$ of the control group newborn samples (birth weight $>\mathrm{m} 2700$ gram and head circumference $>32 \mathrm{~cm}$ ) [Table 1].

CMV-DNA was detected in 4/200 (2\%) of which $3 / 100$ (3\%) belonged to the LBW group and 1/100 $(1 \%)$ to the control group newborn samples (Table 1). Quantitative real-time PCR showed $2.688 \times 10^{5}$, $4.414 \times 10^{5}$ and $5 \times 10^{5}$ CMV-DNA copies $/ \mathrm{ml}$ for the three LBW newborns, and $1.144 \times 10^{6}$ copies $/ \mathrm{ml}$ for a newborn who weighed more than $2.7 \mathrm{~kg}$ (Table 2). All four newborns were delivered in the public AlZahrawi hospital for Gynecology and Obstetrics in Damascus.

\section{Discussion}

Our findings showed that $2 \%$ of the tested newborns had CMV-DNA in their umbilical cord blood. This is inconsistent with other studies [6] showing $0.5 \%$ of infants tested had CMV-DNAemia detected in cord blood. This relatively high level of incidence could be due to the fact that our studied neonates belonged to a low to moderate socioeconomic level.

CMV-IgM antibodies assessment in umbilical cord blood was incapable of detecting congenital CMV infection in newborns. This might be due to the undetectable amount of CMV-IgM antibodies in cord blood by the method used, the insensitivity of CMVIgM measurement in detecting congenital CMV infection [10], and/or delayed development of CMV$\operatorname{IgM}$ in infected fetuses [2].

Likewise, CMV-IgG antibodies evaluation in umbilical cord blood was not a potential discriminative test to identify congenitally infected newborns. This might be due to the high prevalence of CMV seropositivity in the population, and the possibility of IgG antibodies transmission from mothers to fetuses.

CMV-DNA was detected in one newborn whose birth weight and head circumference were normal. Moreover, this newborn demonstrated the highest viral load compared to the three low birth weight and small head circumference newborns. Hence, our data suggest that low birth weight and small head circumference could not be distinctive indicators for congenital CMV infection.

The limitations of our study include (i) the lack of long-term follow up data for infected infants; (ii) study design precluded inclusion of neonatal urine culture as a gold standard method; and (iii) the timing of maternal CMV seroconversion couldn't be assessed by early pregnancy serology. Albeit designed and accepted by mothers when they signed their consents, they were reluctant to give blood samples due to their painful status.

In conclusion, real-time PCR is recommended as a non-invasive, rapid, sensitive screening method for CMV-DNA in umbilical cord blood at the time of delivery for all newborns regardless of their manifestations and serological profile. 
Table 1. Distribution of CMV-IgM and CMV-IgG antibodies and CMV-DNA in umbilical cord blood of LBW group and control group newborns

\begin{tabular}{|c|c|c|c|c|c|c|c|}
\hline $\begin{array}{c}\text { Newborns } \\
\text { group }\end{array}$ & $\begin{array}{c}\text { No. of } \\
\text { newborn } \\
\text { s tested }\end{array}$ & \multicolumn{2}{|c|}{ CMV-IgM } & \multicolumn{2}{c|}{ CMV-IgG } & \multicolumn{2}{c|}{ CMV-DNA } \\
\hline & Positive & Negative & Positive & Negative & Positive & Negative \\
\hline LBW & $\mathrm{N}=100$ & $\begin{array}{c}\mathrm{N}=0 \\
0 \%\end{array}$ & $\begin{array}{c}\mathrm{N}=100 \\
100 \%\end{array}$ & $\begin{array}{c}\mathrm{N}=90 \\
90 \%\end{array}$ & $\begin{array}{c}\mathrm{N}=10 \\
10 \%\end{array}$ & $\begin{array}{c}\mathrm{N}=3 \\
3 \%\end{array}$ & $\begin{array}{c}\mathrm{N}=97 \\
97 \%\end{array}$ \\
\hline $\begin{array}{c}\text { Control } \\
\text { newborns }\end{array}$ & $\mathrm{N}=100$ & $\begin{array}{c}\mathrm{N}=0 \\
0 \%\end{array}$ & $\begin{array}{c}\mathrm{N}=100 \\
100 \%\end{array}$ & $\begin{array}{c}\mathrm{N}=80 \\
80 \%\end{array}$ & $\begin{array}{c}\mathrm{N}=20 \\
20 \%\end{array}$ & $\begin{array}{c}\mathrm{N}=1 \\
1 \%\end{array}$ & $\begin{array}{c}\mathrm{N}=99 \\
99 \%\end{array}$ \\
\hline
\end{tabular}

*: newborns with birth weight $\leq 2.7 \mathrm{~kg}$, and head circumference $\leq 32 \mathrm{~cm}$

$\dagger$ : newborns with birth weight $>2.7 \mathrm{~kg}$ and head circumference $>32 \mathrm{~cm}$.

Table 2. Viral load in CMV-DNA positive newborns born in Al-Zahrawi hospital.

\begin{tabular}{|c|c|c|c|c|}
\hline $\begin{array}{c}\text { Infected } \\
\text { newborns }\end{array}$ & Hospital & $\begin{array}{c}\text { Weight } \\
(\mathbf{g})\end{array}$ & $\begin{array}{c}\text { Head } \\
\text { circumference } \\
(\mathbf{c m})\end{array}$ & $\begin{array}{c}\text { CMV-DNA } \\
(\text { copies/ml })\end{array}$ \\
\hline First $\circlearrowleft$ & $\begin{array}{c}\text { Al- } \\
\text { Zahrawi* }\end{array}$ & 1500 & 28 & $2.688 \times 10^{5}$ \\
\hline Second $q$ & Al-Zahrawi & 2700 & 29 & $4.414 \times 10^{5}$ \\
\hline Third + & Al-Zahrawi & 1600 & 30 & $5.000 \times 10^{5}$ \\
\hline Fourth $\odot \dagger$ & Al-Zahrawi & 2900 & 40 & $1.144 \times 10^{6}$ \\
\hline
\end{tabular}

*:Al-Zahrawi hospital for Gynecology and Obestritic (Free public hospital)

$\dagger$ : Newborn belongs to control group (birth weight $>2.7 \mathrm{~kg}$ and head circumference $>32 \mathrm{~cm}$ ) 


\section{References}

1. Paixão $P$, Almeida S, Gouveia P, Binda S, Caroppo S, Barbi M (2005) Diagnosis of congenital cytomegalovirus infection by detection of viral DNA in urine pools. J Virol Methods 128:1-5.

2. Ornoy A, Diav-Citrin Orna (2006) Fetal effects of primary and secondary cytomegalovirus infection in pregnancy. Reprod Toxicol 21:399-409.

3. Griscelli F, Barrois M, Chauvin S, Lastere S, Bellet D, and Bourhis JH (2001) Quantification of human cytomegalovirus DNA in bone marrow transplant recipients by real-time PCR. J Clin Microbiol 39:4362-4369.

4. Lazzarotto T, Guerra B, Lanari M, Gabrielli L, Landini MP (2008) New advances in the diagnosis of congenital cytomegalovirus infection. J Clin Virol 41:192-7.

5. McCarthy FP, Jones C, Rowlands S, Giles M (2009) Primary and secondary cytomegalovirus in pregnancy. The Obstetrician \& Gynaecologist 11:96-100.

6. Theiler RN, Caliendo AM, Pargman S, Raynor BD, Berga S, McPheeters M, Jamieson DJ (2006) Umbilical cord blood screening for cytomegalovirus DNA by quantitative PCR. J Clin Virol. 37:313-316.

7. Bai X, Hosler G, Rogers BB, Dawson DB, Scheuermann RH (1997) Quantitative polymerase chain reaction for human herpesvirus diagnosis and measurement of EpsteinBarr virus burden in posttransplant lymphoproliferative disorder. Clin Chem 43:1843-1849.
8. Schaade L, Kockelkorn P, Ritter K, Kleines M (2000) Detection of cytomegalovirus DNA in human specimens by LightCycler PCR. J Clin Microbiol 38:4006-4009.

9. Habbal W, Monem F, Gärtner BC (2005) Errors in published sequences of human cytomegalovirus primers and probes: do we need more quality control? J Clin Microbiol 43:5408-9.

10. Schlesinger Y, Halle D, Eidelman AI, Reich D, Dayan D, Rudensky B, Raveh D, Branski D, Kaplan M, Shefer V, Miron D (2003) Urine polymerase chain reaction as a screening tool for the detection of congenital cytomegalovirus infection. Arch Dis Child Fetal Neonatal Ed 88:F371-F374.

\section{Corresponding author}

Fawza Monem

Clinical Laboratories Department

Al-Assad Hospital, Damascus University

PO Box 10769, Damascus, Syria

Phone: +963-11-21942320

Fax: +963-11-2139441

Email: fawzamonem@hotmail.com

Conflict of interest: No conflict of interest is declared. 